\title{
MEMBANGUN TOLERANSI DI SEKOLAH; Sebuah Eksplorasi Nilai-Nialai Pendidikan Toleransi
}

\author{
Tamsir \\ Guru di PAI SMA Negeri I \\ e-mail: tamsirspdi2@gmail.com
}

\begin{abstract}
Abstrak
Artikel ini membicarakan tentang bagaimana konsep toleransi dalam Islam, yaitu tasamuh, dapat diimplementasikan dalam pendidikan. Pendidikan sebagai sebuah sistem, sangat penting mengembangkan konsep ini, lebih-lebih kondisi bangsa Indonesia yang sangat pluralistik. Diantara upaya pengembangan nilainilai pendidikan toleran adalah Pertama, Belajar dalam perbedaan; Kedua, Membangun saling percaya; Ketiga, Memelihara saling pengertian; dan Keempat, Menjunjung tinggi sikap saling menghargai.
\end{abstract}

Keywords: toleransi, pendidikan, Islam

\section{Pendahuluan}

Di era global, plural, multi kultural seperti sekarang, setiap saat dapat saja terjadi peristiwa-peristiwa yang tidak dapat terbayangkan dan tidak terduga sama sekali. Selain membawa kemudahan dan kenyamanan hidup umat manusia, kemajuan ilmu dan teknologi juga membawa akibat pada melebarnya perbedaan tingkat pendapatan ekonomi antara negara-negara kaya dengan negara miskin. Alat transportasi yang semakin cepat dan canggih berdampak pada hilangnya jarak antara satu wilayah pemangku tradisi keagamaan tertentu dengan pemegang tradisi keagamaan yang lain.
Kontak-kontak budaya semakin cepat dan pergesekan kultur serta tradisi tidak terhindarkan, yang bahkan tidak lagi mengenal batas-batas geografis secara konvensional. Internet, e-mail, faksimile, telepon, mobile phone, video dan sebagainya menjadikan anak didik memperoleh pengetahuan lebih cepat dari gurunya (Abdullah, 2005:4).

Salah satu bentuk perubahan manusia yang bersifat global dan berhubungan dengan komunitas muslim adalah perubahan perilaku dan fungsi lembaga keagamaan. Berbagai nilai yang tumbuh dan berkembang dari cara manusia merealisasi ajaran agamanya mulai 
dipertanyakan fungsinya dalam modernitas kehidupan masyarakat.

Tidak dapat ditutupi oleh siapapun bahwa fenomena modernitas yang belakangan terjadi ternyata berbarengan dengan munculnya fenomena kebangkitan agama-agama dunia yang pada saat yang sama juga tercium aroma konflik antar pemeluk agama. Sebuah keniscayaan bahwa dalam masyarakat yang multi agama seringkali timbul pertentangan antar pemeluk agama yang berbeda. Secara umum konflik antar pemeluk agama tersebut disebabkan oleh beberapa faktor antara lain seperti: pelecehan terhadap agama dan pemimpin spiritual sebuah agama tertentu, perlakuan aparat yang tidak adil terhadap pemeluk agama tertentu, kecemburuan ekonomi dan pertentangan kepentingan politik (Yaqin, 2005:51-52).

Ketegangan intra beragama dan antar umat beragama senantiasa menghiasi perjalanan bangsa ini. Sudah banyak konflik terjadi dalam satu dasawarsa terakhir. Korban tewas dalam konflik sudah tak terhitung. Rumah-rumah peribadatan hancur, sebagian hangus di bakar, sebagian luluh lantak dirobohkan, dan sebagian lainnya rusak oleh amuk massa yang terbakar api kemarahan bersentimen keagamaan (Syarbaini, 2011:2-3).

Salah satu bagian penting dari konsekuensi tata kehidupan global yang ditandai kemajemukan etnis, budaya, dan agama tersebut, adalah membangun dan menumbuhkan kembali semangat bertasâmub dalam masyarakat. Karena pada hakikatnya kita semua adalah sebagai seorang "saudara" dan "sahabat". Bahkan, Islam melalui Al-Qur'an dan Hadistnya juga mengajarkan sikap-sikap toleran.

Dalam kaitannya yang langsung dengan prinsip inilah Allah, di dalam AlQur'an surat Yunus ayat 99, menegur keras Nabi Muhammad SAW ketika beliau menunjukkan keinginan dan kesediaan yang menggebu untuk memaksa manusia menerima dan mengikuti ajaran yang disampaikanya, sebagai berikut:

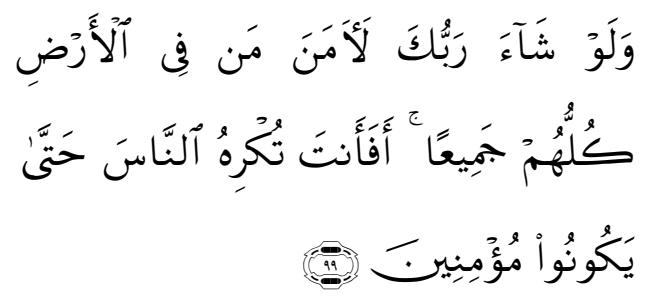

Dan jikalau Tuhanmu menghendaki, tentulah beriman semua orang yang di muka bumi seluruhnya. Maka Apakah kamu (hendak) memaksa manusia supaya mereka menjadi orang-orang yang beriman semuanya (QS. Yunus: 99)

Menurut Shihab (2005:164), ayat di atas telah mengisyaratkan bahwa manusia diberi kebebasan percaya atau tidak. Kaum Nabi Yunus yang tadinya enggan beriman, dengan kasih sayang Allah swt. yang telah memberi peringatan kepada mereka, hingga kaum Yunus yang tadinya membangkang, kemudian atas kehendak mereka sendiri mereka sadar dan beriman. 
Demikianlah prinsip dasar Al-Qur'an yang berkaitan dengan masalah pluralisme dan toleransi. Karena Islam menilai bahwa syarat untuk membuat keharmonisan adalah pengakuan terhadap komponenkomponen yang secara alamiah berbeda.

Salah satu jalan dalam menumbuhkan dan mengkonstruksi ber-tasâmuh tersebut adalah melalui pendidikan. Karena pendidikan memiliki peranan urgen membentuk karakter anak didik sebagai upaya memenuhi tuntutan era modern dan global sekarang ini, dimana seluruh elemen masyarakat bertanggung jawab terciptanya perdamaian abadi. Dalam hal ini pendidikan agama sebagai media penyadaran umat perlu mengembangkan nilai-nilai bertoleransi antar umat beragama (Ma’arif, 2005:vii).

Sebagai lembaga pendidi, maka semua sekolah maupun Pendidikan Islam memiliki tantangan berat untuk merubah paradigma berpikir manusia dari eksklusif menuju inklusif. Permusuhan menjadi persaudaraan, karena pada hakekatnya pendidikan adalah suatu proses dari "upaya memanusiakan manusia" (Ludjito, 1996:21). Ini mengandung maksud bahwa tanpa adanya media berupa pendidikan maka teologi plural akan sulit berkembang di bumi nusantara ini.

Pendidikan dan ilmu pengetahuan adalah sesuatu yang agung karena dengan pendidikan kita, dapat membuka cakrawala untuk melihat kenyataan yang terjadi dalam masyarakat. Termasuk di dalamnya keragaman atau heterogenitas (kemajemukan). Harapan dari pendidikan tersebut, jangan ada lagi monopoli kebenaran (truth claim) atas suatu kelompok.

\section{Makna Toleransi}

Toleransi dalam Dictionary of English Language (1979) disebutkan, bahwa toleransi berarti: "The capacity for or practice of allowing or respecting the nature, beliefs, or behavior or others". Toleransi (tasâmub) adalah modal utama dalam menghadapikeraaman dan perbedaan (yanawnu'iyyah).

\section{Dalam Kamus Besar Bahasa Indonesia} (2005:1204) toleransi berarti bersifat atau bersikap menghargai, membiarkan, membolehkan pendirian (pendapat, pandangan kepercayaan) yang berbeda atau bertentangan dengan pendirian sendiri.

Secara normative, toleransi merupakan salah satu diantara sekian ajaran inti dari Islam. Toleransi sejajar dengan ajaran fundamental yang lain, seperti kasih sayang (rahmah), kebijaksanaan (bikmah), kemaslahatan universal (al-maslabah al-ammah), dan keadilan (Syarbini, 2011:20-21).

Menjadi toleran adalah membiarkan atau membolehkan orang lain menjadi diri mereka sendiri, menghargai orang lain, dengan menghargai asal-usul dan latar belakang mereka. Toleransi mengundang 
dialog untuk mengkomunikasikan adanya saling pengakuan. Inilah gambaran toleransi dalam bentuknya yang solid (Syarbini, 2011:136).

Toleransi bisa bermakna penerimaan kebebasan beragama dan perlndungan undang-undang bagi hak asasi manusia dan warga negara. Toleransi adalah sesuatu yang mustahil untuk dipikirkan dari segi kejiwaan dan intelektual dalam hegemoni sistem-sistem teologi yang saling bersikap ekslusif (Baidhawi, 2001).

Jika pengertian ini diimplementasikan dalam kehidupan beragama, maka dapat berarti mengakui, menghormati dan membiarkan agama atau kepercayaan orang lain untuk hidup dan berkembang.

Adapun sebagai prinsip metodologis, toleransi adalah penerimaan terhadap yang tampak sampai kepalsuannya tersikap. Toleransi relevan dengan epistemologi, juga relevan dengan kata etika sebagi prinsip menerima apa yang dikehendaki sampai ketidaklayakannya tersikap. Sekaligus keyakinan bahwa keanekaragaman agama terjadi karena sejarah dengan semua faktor yang mempengaruhinya, kondisi ruang dan waktunya yang berbeda, prasangka, keinginan dan kepentingannya. Dibalik keanekaragaman agama berdiri al-din albanif, agama fitrah Allah, yang mana manusia lahir bersamanya sebelum akulturasi membuat manusia menganut agama ini atau itu (Al-Faruqi, 1986).
Dalam hubungannya dengan ini, toleransi pada dasarnya adalah upaya untuk menahan diri agar potensi konflik dapat ditekan. Dan toleransi ini, adalah salah satu ciri pokok masyarakat egalitarian, yang di mana keanekaragaman budaya, etnis, bahasa dan sejenisnya bukan menunjukkan bahwa secara kodrati, yang satu lebih baik dari yang lain melainkan agar masing-masing saling mengenal, memahami, dan bekerja sama. Untuk itu diperlukan sikap saling pengertian, saling menghormati, dan menghargai, terbuka dan lapang dada (Mukti, 2002).

Dengan demikian, yang dimaksud konsep toleransi di sini adalah suatu sikap saling mengerti, memahami, dan menghormati adanya perbedaanperbedaan demi tercapainya kerukunan antar umat beragama. Dan dalam berinteraksi dengan aneka ragam agama tersebut, diharapkan masih memiliki komitmen yang kokoh terhadap agama masing-masing.

Ada beberapa prinsip toleransi (Tasâmub) yang dapat ditelusuri dalam alQur'ân, yaitu pengakuan adanya pluralitas dan berlomba dalam kebajikan, interaksi dalam beragama, serta keadilan dan persamaan dalam perlakuan. Menjaga hubungan baik dan kerjasama antar umat beragama yang terdiri dari menjaga hubungan baik antar sesama umat beragama, dan kerjasama antar sesama umat beragama. 
Salah satu ayat yang dijadikan dasar untuk bersikap tasamuh ini adalah :

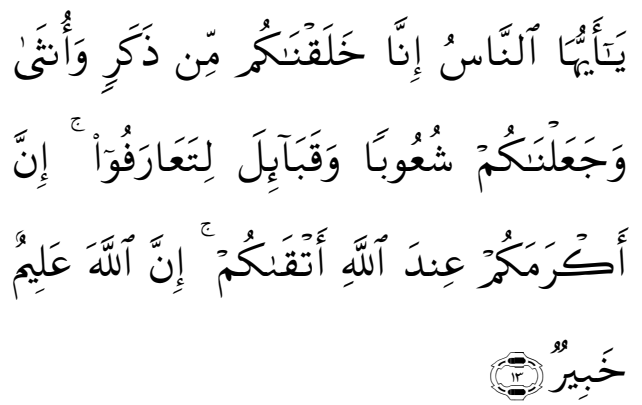

"Hai manusia, sesungguhnya Kami menciptakan kamu dari seorang lakilaki dan seorang perempuan dan menjadikan kamu berbangsa-bangsa dan bersuku-suku supaya kamu saling kenal-mengenal. Sesungguhnya orang yang paling mulia diantara kamu disisi Allah ialah orang yang paling taqwa diantara kamu. Sesungguhnya Allah Maha Mengetahui lagi Maha Mengenal." (Q.S Al-Hujurat : 13) ${ }^{1}$

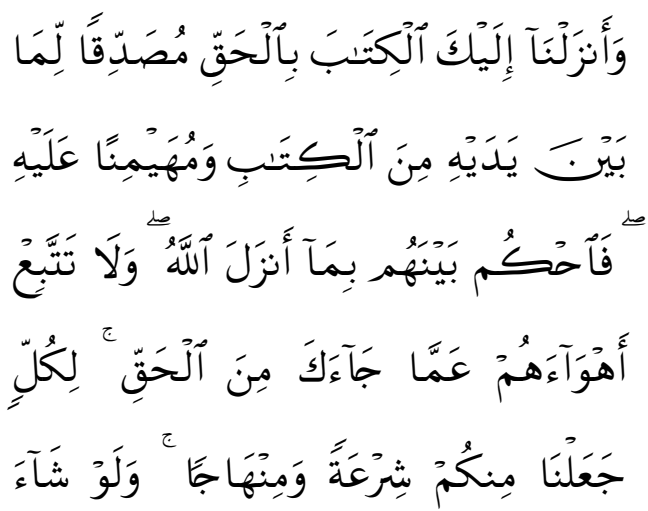

\footnotetext{
Menurut Quraish Shihab (2004:261) berdasarkan riwayat Abû Dâwûd bahwa Q.S alHujurat ayat 13 ini turun berkenaan dengan Abû Hind yang pekerjaan sehari-harinya adalah pembekam. Nabi meminta agar Bani Bayadhah agar menikahkan salah seorang puteri mereka dengan Abû Hind, tetapi mereka enggan dengan alasan tidak wajar mereka menikahkan puteri mereka dengannya yang merupakan salah seorang bekas budak mereka. Sikap keliru ini dikecam oleh al-Qur'ân dengan menegaskan bahwa kemuliaan di si Allah bukan karena keturunan atau garis kebangsawanan tetapi karena ketaqwaan.
}

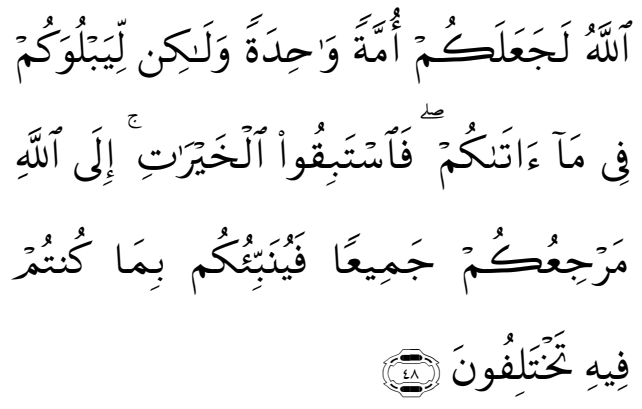

Dan Kami telah menurunkan alQur'ân kepadamu dengan membawa kebenaran, mengkonfirmasi dan menjadi batu ujian terhadap kitabkitab yang ada sebelumnya; maka putuskan perkara mereka menurut apa yang diturunkan Allah dan janganlah engkau mengikuti hawa nafsu mereka dengan mengikuti hawa nafsu mereka dengan meninggalkan kebenaran yang telah datang kepadamu. Untuk masing-masing dari kamu (umat manusia) telah Kami tetapkan hukum (syariah) dan jalan hidup (minhaj). Jika Allah menghendaki, maka tentulah Ia jadikan kamu sekalian umat yang tunggal (monolitik). Namun Ia hendak menguji kamu sekalian berkenaan hal-hal yang telah dikaruniakan-Nya kepada kamu. Maka berlombalah kamu sekalian untuk berbuat kebajikan. Kepada Allah-lah tempat kalian semua kembali, maka Ia akan menjelaskan kepadamu sekalian tentang perkara yang pernah kamu perselisihkan." (Q.S Al-Maidah : 48)

Ayat ini dengan jelas menganjurkan suatu interaksi ko-eksistensi yang konstruktif dan penuh kedamaian, atau bahkan ayat ini mendesak kita untuk dengan segera menciptakan suatu masyarakat global yang terintegrasi (Alwi, 2004:16). 
Selanjutnya, didalam al-Qur'ân diyatakan bahwa pluralitas adalah salah satu kenyataan objektif komunitas umat manusia, sejenis hukum Allah atau sunnah Allah, dan bahwa hanya Allah yang tahu dan dapat menjelaskan, di hari akhir nanti, mengapa manusia berbeda satu dari yang lain.

Muhammad Asad sebagaimana
dikutip oleh Nurcholish Madjid
(1998:108-109), salah seorang penafsir AlQur'ân dalam tafsirnya atas ayat di atas menyatakan:

"Pernyataan "masing-masing dari kamu" di atas menunjuk kepada berbagai komunitas yang membentuk umat manusia secara keseluruhan. Kata syir'ah (atau syari'ah) secara harfiah berarti "jalan menuju kepada sumber air" (dari mana manusia dan binatang memperoleh unsur yang tidak dapat dipisahkan dari hidup mereka), dan dalam Al-Qur'ân digunakan untuk menunjuk ke sistem hukum yang harus ada untuk mencapai kebaikan sosial dan spiritual sebuah komunitas. Kata minhâj, pada sisi lain menunjuk kepada "jalan yang terbuka", khususnya kata dalam pengertian abstrak: yakni, jalan hidup.

Ayat ini menurut Baidhawi (2002:49

52) setidaknya mengandung tiga rinsip utama berkaitan dengan hidup dalam keragaman dan perbedaan, yaitu: Pertama, Prinsip plural is usual. Yakni, kepercayaan dan praktek kehidupan bersama yang menandaskan kemajemukan sebagai sesuatu yang lumrah dan tidak perlu diperdebatkan apalagi dipertentangkan.
Kedua, Prinsip equal is usual. Ayat tersebut merupakan normatifitas bagi kesadaran baru bagi manusia mengenai realitas dunia yang plural. Kesadaran ini bukan hanya karena manusia telah mampu melihat jumlah etnis dan bangsa yang sangat beragam di dunia ini. Namun kesadaran itu telah mengalami perkembangan sesuai dengan episteme zamannya.

Ketiga, Prinsip sahaja dalam keragaman (modesty in diversity). Bersikap dewasa dalam merespon keragaman menghendaki kebersahajaan; yakni sikap moderat yang menjamin kearifan berpikir (open mind) dan bertindak; jauh dari fanatisme yang sering melegitimasi penggunaan instrumen kekerasan dan membenarkan dirty hands (tangan berlumuran darah dan air mata orang tak berdosa) untuk mencapai tujuan apapun; mendialogkan berbagai pandangan keagamaan dan kultural tanpa diiringi tindakan pemaksaan.

Salah satu dimensi dari tujuan Pendidikan Islam adalah perbedaan individu, walaupun ada persamaannya tetapi dalam kenyataannya menunjukkan bahwa manusia sebagai individu secara fitrah memiliki perbedaan. Selain itu perbedaan tersebut juga terdapat kadar kemampuan yang dimiliki masing-masing individu. Jadi secara fitrah, manusia memiliki perbedaan individu (individual differential) yang unik. 
Sehubungan dengan itu, maka tujuan pendidikan diarahkan pada usaha membimbing dan mengembangkan potensi anak didik secara optimal, dengan tidak mengabaikan adanya faktor perbedaan individu serta menyesuaikan pengembangannya dengan kadar kemampuan yang dimiliki masing-masing individu.

Perbedaan individu inilah yang memunculkan sikap toleransi, karena adanya perbedaan individu tersebut maka manusia bisa mengambil hikmah dari perbedaan tersebut yaitu dengan menghargai perbedaan dan mampu bekerja sama dengan orang lain yang berbeda karakter, sikap, aliran, suku, agama, dan lain-lain. Jadi toleransi dalam Pendidikan Islam adalah bagaimana seorang guru mampu berperan diantara para siswa yang berbeda dan mengakomodasikannya sehingga diantara para siswa tersebut mampu saling menghargai, menghormati, toleran dan mampu bekerja sama. Ini merupakan indikasi adanya nilai-nilai toleransi dalam Pendidikan Islam yang bertujuan sosial dalam aktualisasi diri manusia dengan masyarakat di sekitarnya.

\section{Landasan Toleransi Beragama dalam} Islam

Pada dasarnya setiap agama membawa kedamaian dan keselarasan hidup. Namun kenyataannya agama-agama yang tadinya berfungsi sebagai pemersatu tak jarang menjadi suatu unsur konflik.
Hal tersebut disebabkan adanya truth claim atau klaim kebenaran pada setiap penganutnya. Padahal jika dipahami lebih mendalam kemajemukan diciptakan untuk membuat mereka saling mengenal, memahami, dan bekerjasama satu sama lain (Syarbini, 2011:129-130).

Ajaran Islam menganjurkan untuk selalu bekerjasama dengan orang lain dan saling tolong menolong dengan sesama manusia. Hal ini menggambarkan bahwa umat Islam diperintahkan untuk menjaga kerukunan umat beragama baik yang seagama maupun yang berbeda agama. Bentuk universalisme Islam digambarkan pada ketidakadaanya paksaan bagi manusia dalam memeluk agama Islam. Hal ini menunjukkan bahwa Islam adalah agama yang menghormati agama lain (Syarbini, 2011:129-130).

Pluralitas merupakan hukum ilahi dan sunnah ilahiyah yang abadi di semua bidang kehidupan, sehingga pluralitas itu sendiri telah menjadi karakteristik utama makhluk Allah pada level syari'at, way of life, dan peradaban, semua bersifat plural. Pluralitas merupakan realitas yang mewujud dan tidak mungkin dipungkiri, yaitu suatu hakikat perbedaan dan keragaman yang timbul semata karena memang adanya kekhususan dan karakteristik yang diciptakan Allah swt dalam setiap ciptaan-Nya. Pluralitas yang menyangkut agama yaitu toleransi beragama berarti pengakuan akan eksistensi agama-agama yang berbeda dan beragama dengan seluruh karakteristik dan 
kekhususannya dan menerima kelainan yang lain beserta haknya untuk berbeda dalam beragama dan berkeyakinan (Thoha, 2005:206-207).

Konsep dan pemahaman toleransi beragama seperti ini didukung oleh dalil naql (teks wahyu), akal dan kenyataan. Allah berfirman dalam surat Al-Baqarah ayat 256 .

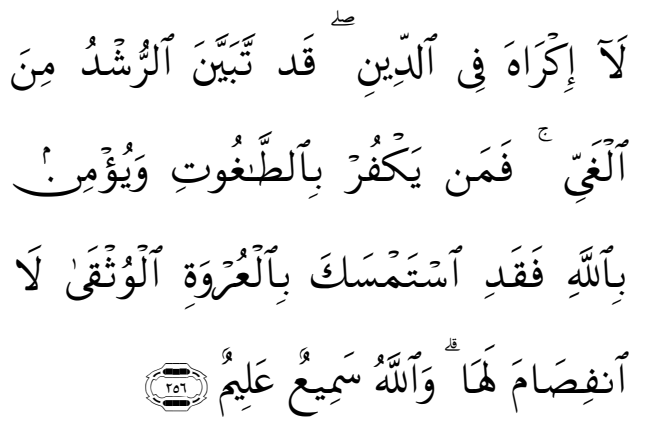

"Tidak ada paksaan untuk (memasuki) agama (Islam); Sesungguhnya telah jelas jalan yang benar daripada jalan yang sesat. karena itu Barangsiapa yang ingkar kepada Thaghut dan beriman kepada Allah, Maka Sesungguhnya ia telah berpegang kepada buhul tali yang Amat kuat yang tidak akan putus. dan Allah Maha mendengar lagi Maha mengetahui."

Dalam surah Al-baqarah ayat 256 patut menjadi perhatian bersama agar dalam dakwah dapat mempertimbangkan aspek toleransi dan kasih sayang yang telah digariskan oleh Allah dan Rasulullah. Tidak diperkenankan adanya pemaksaan, karena Memaksakan kehendak bukanlah hak manusia.

Sesungguhnya antara kebaikan dan kezaliman sudah jelas. Kalimat larangan ini diungkapkan dalam bentuk negatif secara mutlak. "Laa ikraaha fid din' tidak ada paksaan untuk "memasuki" agama “Islam". Menurut Sayyid Quthb (2000: 42343) ungkapan ini menegasikan semua bentuk pemaksaan, meniadakan pemaksaan secara mendasar.

Dalam ayat diatas tidak ada paksaan dalam menganut agama. Mengapa ada paksaan, padahal agama tidak butuh sesuatu, mengapa ada paksaan padahal sekiranya Allah menghendaki, niscaya kamu dijadikan-Nya satu umat saja. (QS. Al-maidah: 48). Yang dimaksud dengan tidak ada paksaan dalam menganut agama adalah menganut akidahnya. Ini berarti jika seseorang telah menganut satu akidah maka dia terkait dengan tuntunantuntunanya. Dia berkewajiban melaksanakan perintah-perintahnya Quraish Shihab (2005:550).

Menurut Al-Qaradhawi dalam Anis Malik Thoha (2005:215) menyebutkan empat faktor utama yang menyebabkan toleransi yang unik selalu mendominasi perilaku orang Islam terhadap nonMuslim. Pertama, keyakinan terhadap kemuliaan manusia, apapun agamanya, kebangsaannya, dan kesukuannya. Kemuliaan mengimplikasikan hak untuk dihormati.

"Diriwayatkan dari Jabir bin Abdullah r.a: Jenazah (yang diusung ke pemakaman) lewat dihadapan kami. Nabi Muhammad Saw berdiri dan kami pun berdiri. Kami berkata, "Ya Rasulullah ini jenazah orang Yahudi" Ia berkata," Kapanpun 
kalian melihat jenazah (yang diusung ke pemakaman), berdirilah."

Dari Hadits tersebut jelas bahwa Nabi Muhammad tidak pernah membedabedakan, sikap toleransi itu direfleksikan dengan cara saling menghormati, saling memuliakan dan saling tolong-menolong. Jadi sudah jelas, bahwa sisi aqidah atau teologi bukanlah urusan manusia, melainkan Tuhan SWT dan tidak ada kompromi serta sikap toleran di dalamnya. Sedangkan kita bermu amalah dari sisi kemanusiaan kita.

Kedua, Keyakinan bahwa perbedaan manusia dalam agama dan keyakinan merupakan realitas yang dikehendaki Allah swt yang telah memberi mereka kebebasan untuk memilih iman atau kufur. Kehendak Allah pasti terjadi, dan tentu menyimpan hikmah yang luar biasa. Oleh karenanya, tidak dibenarkan memaksa untuk Islam. Allah berfirman dalam sebuah ayat di surat Yunus ayat 99 :

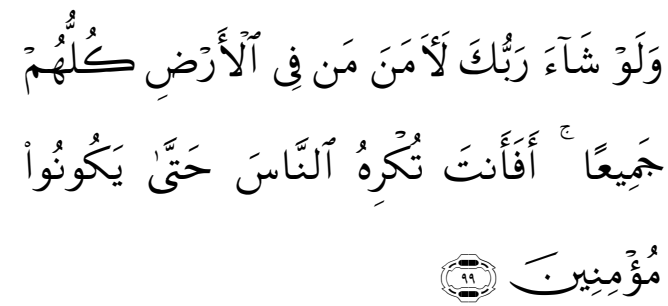

"Dan Jikalau Tuhanmu menghendaki, tentulah beriman semua orang yang di muka bumi seluruhnya. Maka Apakah kamu (hendak) memaksa manusia supaya mereka menjadi orang-orang yang beriman semuanya".

Ayat diatas telah mengisyaratkan bahwa manusia diberi kebebasan percaya atau tidak. Seperti dicontohkan, kaum
Yunus yang tadinya enggan beriman, dengan kasih sayang Allah swt. memperingatkan dan mengancam mereka. Hingga kemudian kaum Yunus yang tadinya membangkang atas kehendak mereka sendiri, kini atas kehendak mereka sendiri pula mereka sadar dan beriman (Shihab, 2005:164).

Ketiga, Seorang muslim tidak dituntut untuk mengadili kekafiran orang kafir, atau menghukum kesesatan orang sesat. Allah-lah yang akan mengadili mereka di hari perhitungan nanti. Dengan demikian hati seorang muslim menjadi tenang, tidak perlu terjadi konflik batin antara kewajiban berbuat baik dan adil kepada mereka, dan dalam waktu yang sama, harus berpegang teguh pada kebenaran keyakinan sendiri. Allah swt. berfirman dalam surat Al-Kahfi ayat 29:

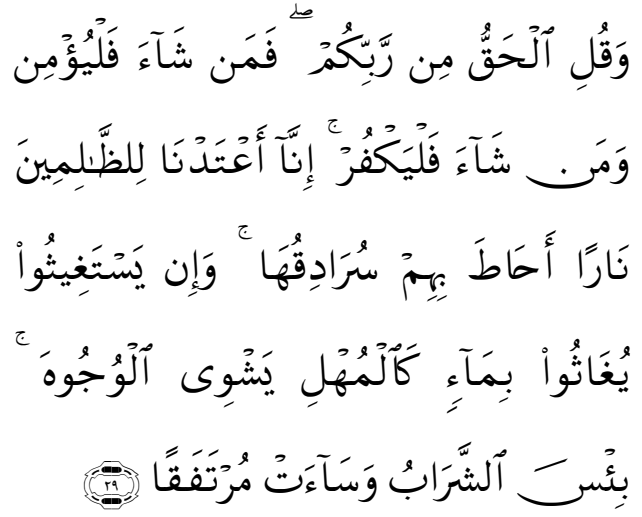

"Dan Katakanlah: "Kebenaran itu datangnya dari Tuhanmu; Maka Barangsiapa yang ingin (beriman) hendaklah ia beriman, dan Barangsiapa yang ingin (kafir) Biarlah ia kafir". Sesungguhnya Kami telah sediakan bagi orang-orang zalim itu neraka, yang gejolaknya mengepung 
mereka. dan jika mereka meminta minum, niscaya mereka akan diberi minum dengan air seperti besi yang mendidih yang menghanguskan muka. Itulah minuman yang paling buruk dan tempat istirahat yang paling jelek."

Ayat ini diturunkan untuk memerintahkan Rasul saw. Menegaskan kepada semua kaum termasuk kaum musyrikin bahwa: "dan katakanlah wahai Nabi Muhammad bahwa: "kebenaran, yakni wahyu Ilahi yang aku sampaikan ini datangnya dari Tuhan pemelihara kamu dalam segala hal; maka barang siapa diantara kamu, atau selain kamu yang ingin beriman tentang apa yang kusampaikan ini maka hendaklah ia beriman, keuntungan dan manfaatnya akan kembali pada dirinya sendiri, dan barang siapa diantara kamu atau selain kamu yang ingin kafir dan menolak pesan-pesan Allah, maka biarlah ia kafir, walau sekaya dan setinggi apapun kedudukan sosialnya. Tidaklah aku apalagi Allah swt akan mengalami sedikit kerugian pun dengan kekafirannya, sebaliknya, dialah sendiri yang akan merugi dan celaka dengan perbuatannya yang telah menganiaya dirinya sendiri (Shihab, 2005:52).

Keempat, Keyakinan bahwa Allah swt. memerintahkan untuk berbuat adil dan mengajak kepada budi pekerti mulia meskipun kepada orang musyrik. Begitu juga Allah swt. mencela perbuatan zalim meskipun terhadap orang kafir. Seperti firman Allah swt. dalam surat Al-Maidah ayat 8 :

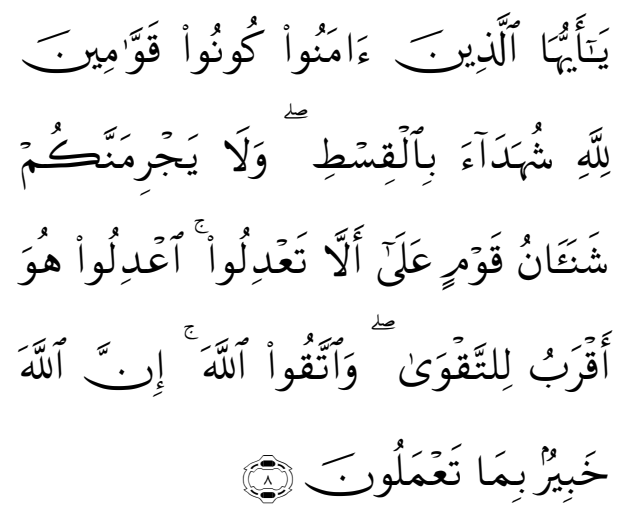

"Hai orang-orang yang beriman hendaklah kamu Jadi orang-orang yang selalu menegakkan (kebenaran) karena Allah, menjadi saksi dengan adil. dan janganlah sekali-kali kebencianmu terhadap sesuatu kaum, mendorong kamu untuk Berlaku tidak adil. Berlaku adillah, karena adil itu lebih dekat kepada takwa. dan bertakwalah kepada Allah, Sesungguhnya Allah Maha mengetahui apa yang kamu kerjakan."

Dalam ayat tersebut Allah melarang ummatnya menebar permusuhan dan kebencian terhadap suatu kaum yang yang dapat mendorong terhadap sikap tidak adil terhadap kaum tersebut. Jadi terhadap merekapun kita harus tetap memberi kesaksian sesuatu dengan hak yang patut mereka terima apabila mereka patut menerimanya. Karena orang mukmin mesti mengutamakan keadilan dari pada berlaku aniaya dan berat sebelah keadilan harus ditempatkan diatas hawa nafsu dan kepentingan-kepentingan pribadi, dan diatas rasa cinta dan permusuhan, apapun sebabnya (Al-Maraghi:1993). 
Beberapa ayat Al-Qur'an diatas menerangkan ungkapan yang sangat tegas dan gamblang mengenai pandangan Islam terhadap kebebasan beragama dan berkeyakinan, yang merupakan ciri kebebasan manusia yang paling utama. Bahkan menurut Sayyid Quthb (2000:343), kebebasan ini merupakan hak asasi manusia yang nomor satu yang tanpanya manusia bukan lagi manusia.

Hal ini juga telah dicontohkan oleh Nabi Muhammad saw. Ditengah masyarakat yang heterogen, yang diwarnai ketegangan-ketegangan konflik, nabi melakukan gerakan besar yang berpengaruh bagi kesatuan ummah.

Pertama, Hijrah, implikasi sosialnya terletak pada persaudaraan antara Muhajirin dan Anshar. Bukan persaudaraan biasa, kaum anshar melapangkan kekayaanya untuk dapat dinikmati pula oleh kaum Muhajirin.

Kedua, piagam Madinah, ketegangan antara Yahudi dan Muslim, baik Anshar Maupun Muhajirin, begitu pula antar kelompok lain dan juga kemajemukan komunitas Madinah membuat Nabi melakukan negosiasi dan konsolidasi melalui perjanjian tertulis yang kemudian familiar disebut Piagam Madinah konstitusi ditanda tangani oleh seluruh komponen yang ada di Madinah yang meliputi Nasrani, Yahudi, Muslim dan Musyrikin.

Dalam 47 pasal yang termuat di dalamnya statement yang diangkat meliputi masalah monotheisme, persatuan kesatuan, persamaan hak, keadilan kebebasan beragama, bela negara, pelestarian adat perdamaian dan proteksi. Konstitusi tersebut memberi tauladan kita tentang pembentukan ummah, menghargai hak asasi manusia dan agama lain, persatuan segenap warga negara, dan yang terpenting adalah tanggung jawab menciptakan kedamaian.

Dengan demikian tampak bahwa nilai-nilai ajaran Islam menjadi dasar bagi hubungan antar umat manusia secara universal, dengan tidak mengenal suku, adat, budaya, dan agama. Akan tetapi yang dilarang Islam hanya pada konsep aqidah dan ibadah. Kedua konsep tersebut yang tidak bisa di campuri oleh umat non Islam. Namun aspek sosial kemasyarakatan dapat bersatu dan kerjasama yang baik.

Perlu ditambahkan bahwa mengakui eksistensi praktis agama-agama lain yang beragam dan saling berseberangan ini, dalam pandangan Islam tidak secara otomatis mengakui legalitas dan kebenarannya. Melainkan menerima kehendak ontologis Allah swt dalam menciptakan agama-agama berbeda-beda dan beragam. Mengakui realitas perbedaan dan hak seorang untuk berbeda sama sekali tidak berarti syari'at dakwah mesti digugurkan.

Bahkan sebaliknya, justru malah semakin menegaskan urgensi dan pentingnya dakwah. Sebab di satu pihak, 
hakikat perbedaan itu sendiri sejatinya memungkinkan masing-masing faksi yang saling berbeda untuk melihat dirinya sebagai entitas yang memiliki kelebihan, nilai dan kebenaran, dan untuk melaksanakan hak-haknya, serta untuk mengekspresikan jati dirinya secara bebas sebagai upaya mewujudkan kelebihan, nilai dan kebenaran yang dimilikinya.

\section{Nilai-nilai Pendikan Toleransi}

Nilai menurut Mulyana (2004:8-10) adalah rujukan dan keyakinan dalam menentukan suatu pilihan. Oleh karena nilai sebagai rujukan dalam bertindak, maka setiap orang harus memperhatikan lebih mendalam agar hati-hati dan berpikir rasional sebelum mengambil tindakan. Seseorang yang bertindak tanpa dasar rujukan yang kuat dapat dianggap tidak memiliki dan memahami nilai moral.

Menurut Judy Lawly (2000), nilai merupakan pedoman kepercayaan yang mendalam mengenai suatu hal yang penting. Nilai secara langsung mempengaruhi perilaku dan tertanam kuat dalam kebudayaan masyarakat dan latar belakang keluarga.

Schwartz (2002:37) mendefinisikan "values as goals and motivations which serve as guiding principles in people's lives". Artinya, nilai sebagai tujuan dan motivasi yang berperan sebagai prinsip-prinsip petunjuk dalam kehidupan manusia. Apabila nilai telah mempribadi dalam kehidupan seseorang, maka akan tampak dalam polapola sikap, niat dan perilakunya.
Menurut Merril (2000:12), nilai adalah patokan atau standar pola-pola pilihan yang dapat membimbing seseorang atau kelompok ke arah "satisfaction, fulfillment, and meaning". Patokan, kriteria, prinsip-prinsip, dan ukuran yang memberi dasar pertimbangan kritis tentang pengertian, estetika, kewajiban moral, dan religius.

Jadi, nilai-nilai pendidikan adalah nilai-nilai yang harus ditanamankan dan dikemmbangkan pada diri seseorang. Mardiatmaja (tt:10) mengemukakan nilainilai pendidikan sebagai bantuan terhadap peserta didik agar menyadari dan mengalami nilai-nilai serta menempatkannya secara integral dalam keseluruhan hidupnya.

Dengan demikian, nilai-nilai pendidikan tidak hanya merupakan program khusus yang diajarkan melalui sejumlah mata pelajaran, tetapi mencakup pula keseluruhan proses pendidikan. Dalam hal ini, yang menanamkan nilai kepada peserta didik bukan saja guru pendidikan nilai dan moral serta bukan saja pada saat mengajarkannya, melainkan kapan dan di manapun, nilai harus menjadi bagian integral dalam kehidupan.

Dari definisi di atas dapat ditarik suatu definisi nilai-nilai pendidikan toleransi mencakup keseluruhan aspek pengajaran atau bimbingan kepada peserta didik agar memiliki modal nilai yang menjadi prinsip dan petunjuk dalam kehidupannya. 
Dengan demikian, mereka menyadari nilai kebenaran, kebaikan, kebersamaan, dan keindahan melalui proses pertimbangan nilai yang tepat dan pembiasaan bertindak yang konsisten. Penekanannya terletak pada peran pendidikan sebagai transformasi nilai sehingga menjadi bagian yang integral dalam diri peserta didik. Dengan memiliki nilai moral, maka segala tindakan peserta didik akan terkontrol karena dilakukan dengan pertimbangan nilai yang matang.

Adapun nilai-nilai pendidikan toleran yang perlu dikembangkan adalah: Pertama, Belajar dalam perbedaan. Pendidikan yang menopang proses dan produk pendidikan nasional hanya bersandar pada tiga pilar utama yang menopang proses dan produk pendidikan nasional, yaitu how to know, how to do, dan how to be. Pada pilar ketiga How to be menekankan pada cara "menjadi orang" sesuai dengan karakteristik dan kerangka pikir anak didik. Dalam konteks ini, how to life and work together with others pada kenyataannya belum secara mendasar mengajarkan sekaligus menanamkan ketrampilan hidup bersama dalam komunitas yang plural secara agama, cultural, ataupun etnik.

Selanjutnya pilar keempat sebagai suatu jalinan komplementer terhadap tiga pilar lainnya dalam praktik pendidikan meliputi proses: pertama, pengembangan sikap toleran, empati, dan simpati, yang merupakan prasyarat esensial bagi keberhasilan dan proeksistensi dalam keragaman agama. Toleransi adalah kesiapan dan kemampuan batin bersama orang lain yang berbeda secara hakiki, meskipun terhadap konflik dengan pemahaman kita. Pendidikan agama dengan menekan kan nilai-nilai toleransi dirancang, di desain untuk menanamkan, :1) sikap toleransi dari tahap yang minimalis, dari yang sekadar dekoratif hingga yang solid. 2) klasifikasi nilai-nilai kehidupan bersama menurut perspektif agama-agama. 3) pendewasaan emosional. 4) kesetaraan dan partisipasi. 5) kontrak sosial baru dan aturan main kehidupan bersama antaragama.

Kedua, Membangun saling percaya. Rasa saling percaya adalah salah satu modal sosial terpenting dalam penguatan masyarakat.

Ketiga, Memelihara saling pengertian. Memahami bukan serta menyetujui. Saling memahami adalah kesadaran bahwa nilainilai mereka dan kita adalah berbeda, dan mungkin saling melengkapi serta memberi kontribusi terhadap relasi yang dinamis dan hidup. Agama mempunyai tanggung jawab membangun landasan etnis untuk bisa saling memahami diantara entitasentitas agama dan budaya yang pluralmultikultural.

Keempat, Menjunjung tinggi sikap saling menghargai. Dengan desain pembelajaran semacam ini, diharapkan akan tercipta sebuah proses pembelajaran yang mampu menumbuhkan kesadaran pluralis dikalangan anak didik. Jika desain 
semacam ini dapat terimplementasi dengan baik, harapan terciptanya kehidupan yang damai, penuh toleransi, dan tanpa konflik lebih cepat akan lebih terwujud. Sebab pendidikan merupakan media dengan kerangka yang paling sistematis, paling luas penyebarannya, dan paling efektif kerangka implementasinya.

\section{Penutup}

Banyak sekali ayat yang berbicara tentang konsepsi Al-Qur'an tentang tasamuh, yaitu menjaga hubungan baik dan kerjasama antar umat beragama dalam Qur'an surat An-Nisa ayat 86, Al-An'am ayat 108, dan Al-Ankabut ayat 46. Kemudian Implikasi dari konsepsi AlQur'an tentang tasamuh terhadap pendidikan Islam adalah perlu diadakannya sebuah pendidikan agama yang inklusif, dan yang kedua adalah menyelenggarakan pendidikan agama yang humanis, yang ketiga adalah perlu adanya sebuah studi perbandingan agama dalam pendidikan agama Islam, serta perlu adanya kurikulum yang humanistik. Proses Pembelajaran perlu sekali mengembangkan Pertama, Belajar dalam perbedaan; Kedua, Membangun saling percaya; Ketiga, Memelihara saling pengertian; Keempat, Menjunjung tinggi sikap saling menghargai.

\section{DAFTAR PUSTAKA}

Abdullah., Amin, 2005., Pendidikan Agama Era Multikultural Multi Religius. Jakarta: PSAP

Al-Maraghi, Ahmad Musthafa., 1993, Tafsir Al-Maraghi terj. Bahrun Abubakar., Semarang: Thoha Putra

Baidhawy, Zakiyuddin., 2002., Pendidikan Agama Berwawasan Multikultural, Jakarta: Penerbit Erlangga

Departemen Agama RI, 2005., Al-Qur'an dan Terjemahnya., Bandung: J-Art.

Isma'il al-Faruqi dan Lois Lamnya alFaruqi, The Cultural Atlas of Islam, (New York: MacMillan Publishing Company, 1986), hlm. 79

Jalaludin, 2001., Teologi Islam, Jakarta: PT. Raja Grafindo Persada,

Lawly., Judy, 2000, "Living Values School" dalam

(http://www.nzpf.ac.nz/resources/maga-zine/b4-2000/articles/living.html).

Lutdjito., Ahmad, 1996., " Filsafat Nilai dalam Islam" dalam Chabib Thoha et.al, Reformulasi Filsafat Pendidikan Islam, Yogyakarta: Pustaka Pelajar dan FT. IAIN Walisongo Semarang

Madjid,., Nurcholish., 1998., Mencari Akar-akar Islam Bagi Pluralisme Modern: Pengalaman Indonesia, dalam Toward A New Paradigm: Developments in Indonesian Islamic Thought, Terj. Ihsan Ali Fauzi, Jalan Baru Islam, (Jakarta: Mizan, 1998), hlm. 108-109.

Mulyana., Rochmat., 2004., Mengartikulasikan Pendidikan Nilai Bandung: Alfabeta 
Mukti., Abdul, 2000., "Masyarakat Egalitarian", dalam Thoha Hamim, at.all, Pendidikan Islam, Demokrasi dan Masyarakat Madani, Semarang: Fakultas Tarbiyah

Pusat Bahasa Departemen Pendidikan Nasional, 2005., Kamus Besar Bahasa Indonesia., Jakarta: Balai Pustaka

Yaqin., Ainul, 2005, Pendidikan Multikultural, Yogyakarta : Pilar Media

Syarbini., Amirulloh, 2011., AlQurIndonesia, (Yogyakarta: Logung Pustaka,), hlm. vii.

Shihab., M. Quraish Shihab, 2004., Tafsir al-Misbâh, Pesan, Kesan dan Keserasian Al-Qur'ân Volume 13, (Jakarta: Lentera Hati, 2004), Cet. II., hlm. 261

Sayyid Quthb, 2000., Fi Drilal Al-Qur'an terj, As'ad Yasin, Jakarta: Gema Insani,

Tafsir Al-Misbah Pesan, Kesan dan Keserasian Al-Qur'an (Jakarta: Lentera Hati, 2005), cet 1, vol 1. hlm. 550.

The Heritage Illustrated Dictionary of The English Language Vol. II, (USA: Houghton Mifflin Company, 1979), hlm. 1351

Thoha., Anis Malik. 2006., Tren Pluralisme Agama: Tinjauan Kritis, Jakarta: Perspektif 